\title{
Does insulin resistance impair the virological response to peginterferon/ribavirin in chronic hepatitis $\mathrm{C}$ genotype 3 patients?
}

\author{
Marcela Pezzoto LAURIT01,2, Giovanni Faria SILVA ${ }^{3}$, Hugo CHEINQUER ${ }^{4}$, Rajani SHARMA², \\ Elizabeth VERNA ${ }^{2}$ and Edison Roberto PARISE ${ }^{1}$
}

\begin{abstract}
Background - Insulin resistance and diabetes mellitus are common extrahepatic manifestations of chronic hepatitis C (HCV). Insulin resistance assessed by HOMA-IR is associated with low rates of sustained virological response, especially in HCV genotype 1 positive patients treated with peginterferon/ribavirin. The effect of insulin resistance on sustained virologic response in HCV genotype 3 positive patients who were treated with peginterferon/ribavirin still remains unclear. Objective - To evaluate the impact of insulin resistance on sustained virological response in HCV genotype 3 patients treated with peginterferon/ribavirin. Methods - A retrospective multicenter study was performed to evaluate the impact of insulin resistance on sustained virological response in non-diabetic HCV genotype 3 positive patients treated with peginterferon and ribavirin. A total of 200 HCV genotype 3 positive patients were enrolled in the study. All patients were non-diabetic. Each patient had a HOMA-IR value measured before the initiation of HCV treatment with peginterferon/ribavirin. The treatment duration was at least 24 weeks. The HOMA-IR cut-off was defined in the study as $\geq 2.5$ due to the coefficient of correlation with sustained virological response of $0.202(P=0.004)$. Results - Univariate analysis showed that age, aspartate aminotransferase, platelets, stage of fibrosis and HOMA-IR were predictors of sustained virological response. However multivariate analysis showed advanced fibrosis [OR=2.01 (95\%CI: 0.986-4.119) $P=0.05]$ and age [OR=1.06 (95\%CI: $1.022-1.110) P=0.002]$ as negative predictors of sustained virological response. Conclusion - In this retrospective multicenter study of non-diabetic HCV genotype 3 positive patients, insulin resistance was not associated with the sustained virological response in patients who were treated with peginterferon/ribavirin.
\end{abstract}

HEADINGS - Chronic hepatitis C. Genotype. Insulin resistance. Ribavirin. Antiviral agents.

\section{INTRODUCTION}

Insulin resistance (IR) and diabetes mellitus (DM) are common extrahepatic manifestations of chronic hepatitis $\mathrm{C}(\mathrm{HCV})^{(1-5)}$. The relationship between $\mathrm{HCV}$ and $\mathrm{DM}$ seems to be related to a direct effect of the HCV on the insulin signaling pathway ${ }^{(6-8)}$.

Insulin resistance assessed by HOMA-IR (Homeostatic model assessment) is associated with low rates of sustained virological response (SVR), especially in genotype 1 positive patients treated with peginterferon/ribavirin $(\mathrm{PEG} / \mathrm{RBV})^{(9-12)}$.

Prior studies have shown that the presence of IR, stratified by genotypes, had a negative effect on SVR rates in patients with genotype 2 or 3 as compared to genotype 1 positive patients [OR $=4.45(95 \%$ CI: $1.59-12.49)$ for genotypes 2,3 vs OR $=2.23(95 \%$ CI: 1.59-3.13) for genotype 1]. ${ }^{(13-20)}$. However, only four studies have assessed the impact of IR on SVR in genotype 3 positive patients alone with differing results ${ }^{(14,15,17,18)}$.

The prevalence of $\mathrm{HCV}$ genotype 3 worldwide is approximately $30 \%$ of global HCV infections and is highly prevalent in low-income regions ${ }^{(21)}$. The majority of these patients are likely to have faster fibrosis progression $^{(22)}$ and a higher risk of developing hepatocellular carcinoma ${ }^{(23)}$.
Despite the advent of new highly effective interferon-free $\mathrm{HCV}$ therapies ${ }^{(24,25)}$, there still remains concern for the optimal treatment for sub-groups of genotype 3 positive patients ${ }^{(26,27)}$. In Latin American, Middle Eastern and African countries where the cost of drugs plays a significant role in available HCV treatment options, PEG/ $\mathrm{RBV}$ with or without sofosbuvir still remains a feasible treatment option $^{(28,29)}$. Therefore, it is still important to understand factors associated with low SVR rates to interferon-based treatment in genotype 3 positive patients alone.

Thus far, the majority of studies that have investigated predictors of SVR on the interferon-based therapies have grouped genotype 3 with genotype 2 . To better understand predictors of SVR, especially IR, in genotype 3 patients, we retrospectively studied treatment-naïve patients exclusively infected with $\mathrm{HCV}$ genotype 3 who underwent treatment with peginterferon plus ribavirin for at least 24 weeks.

\section{METHODS}

A retrospective multicenter study was performed in three academic liver centers in Brazil (Setor de Gastroenterologia, Universidade Federal de São Paulo; Departamento de Medicina, Universidade

Universidade Federal de São Paulo, Disciplina de Gastroenterologia, SP, Brasil. ${ }^{2}$ Columbia University Medical Center, Center for Liver Disease and Transplantation, New York, NY, USA. ${ }^{3}$ Universidade Estadual de São Paulo, Departamento de Medicina, SP, Brasil. ${ }^{4}$ Hospital de Clínicas de Porto Alegre, Departamento de Gastroenterologia, RS, Brasil. 
Estadual de São Paulo; Departamento de Gastroenterologia, Hospital de Clínicas de Porto Alegre, Rio Grande do Sul, Brazil).

The centers included in this study have HCV treatment experience and routinely require fasting insulin and glucose levels prior to initiating HCV therapy. Patients who were HCV genotype 3 positive and received antiviral treatment from 2010 to 2015 were included in this study. All patients were adults with age $\geq 18$ years and whose first treatment regimen was peginterferon and ribavirin (PEG/RBV) for chronic HCV. Fasting insulin and glucose level were measured at least 3 months before initiating HCV therapy, and liver biopsies were taken up to 6 months prior treatment initiation. Patients were treated with weekly peginterferon alpha-2a or alpha $2 \mathrm{~b}$ with ribavirin for at least 24 weeks. Pegylated interferon alpha-2a dose was $180 \mu \mathrm{g}$ and peginterferon alfa $2 \mathrm{~b}$ dose was 1.5 $\mu \mathrm{g} / \mathrm{kg}$ of body weight. Ribavirin doses were $1000 \mathrm{mg} / \mathrm{d}$ in patients $\leq 75 \mathrm{~kg}$ and $1200 \mathrm{mg} / \mathrm{d}$ in patients $>75 \mathrm{~kg}^{(30)}$.

Exclusion criteria included alcohol intake greater than $20 \mathrm{~g} / \mathrm{d}$, a previous diagnosis of diabetes mellitus and the use of oral diabetic medications specifically insulin sensitizers and insulin production simulators. Coinfection with hepatitis B virus or HIV (human immunodeficiency virus) and other liver disease besides hepatitis $\mathrm{C}$, except for NAFLD (nonalcoholic fatty liver disease), were excluded.

\section{Pretreatment characteristics}

Demographics measured included age, gender, and body mass index (BMI - $\mathrm{kg} / \mathrm{m}^{2}$ ). Aspartate aminotransferase (AST), alanine aminotransferase (ALT), alkaline phosphatase and gammaglutamyl transpeptidase (GGT), platelets count $\left(\mathrm{mm}^{3} / \mathrm{mL}\right)$, total cholesterol, HDL-c, LDL-c, triglycerides, and glucose were assessed by automated methods. Insulin serum levels were determined by chemiluminescence. Insulin resistance was determined by HOMAIR where HOMA-Ir is calculated as fasting glucose $(\mathrm{mg} / \mathrm{dL})$ multiplied by fasting insulin (IU/mL) divided by $405^{(31)}$.

Serum HCV-RNA levels were quantified at the beginning of treatment using quantitative reverse-transcription polymerase chain reaction (PCR) (Cobas Amplicor Test - Roche Diagnostic System, USA). For statistical purposes we chose $400,000 \mathrm{IU} / \mathrm{mL}$ as the cut-off value to separate low $(<400,000 \mathrm{IU} / \mathrm{mL})$ from high $(\geq 400,000 \mathrm{IU} / \mathrm{mL})$ viral load. Sustained virological response was defined as undetectable HCV-RNA levels achieved at 24 weeks after treatment completion.

$\mathrm{HCV}$ genotyping was performed by sequencing of the $\mathrm{HCV}$ 5 ' non-coding segment (5'UTR). AST, ALT, GGT, and alkaline phosphatase were analyzed as times of upper limit of normalization (ULN). Lipid panel was defined as total cholesterol level (mg/dL), HDL cholesterol (mg/dL) and triglycerides $(\mathrm{mg} / \mathrm{dL})$.

Liver biopsies were obtained up to 6 months prior treatment. Fibrosis and Activity scores were classified based on Metavir system ${ }^{(32)}$. Patients were divided into two groups according to fibrosis stage: patients with no fibrosis to significant fibrosis (F0-F2); and patients with advanced fibrosis (F3 and F4). Activity score was categorized as mild (A0, A1) or moderate/severe (A2, A3). Hepatic steatosis was scored as the percentage of hepatocytes containing macrovesicular fat droplets and was graded from 0 to 3 (grade $0,<5 \%$ steatosis, grade 1, 5\%-33\% hepatocytes affected; grade $2,33 \%-66 \%$ of hepatocytes affected; grade $3,67 \%$ or more of hepatocytes affected).

This study was performed according to the principles of the Declaration of Helsinki and was approved by the Ethical Institutional Review Board.

\section{Statistical analysis}

Continuous variables are presented as mean \pm standard deviation (SD) and categorical variables as presented as frequency and percentage. The $t$-test was used to compare continuous variables and the Chi-square or Fisher's test was used for categorical variables. The Spearman correlation was used to identify the cut-offs of HOMAIR associated with SVR. To identify the independent predictors of SVR, we used a logistic regression model for variables that showed a level of significance less than 0.05 in univariate analysis. Tests were two-sided, and significance was accepted at $P<0.05$. All analyses were performed with Stata ${ }^{\circledR} 14$ (StataCorp, College Station, TX).

\section{RESULTS}

A total of 200 genotype 3 positive patients were included in this study. Patients' baseline demographic, clinical and virological characteristics are showed in TABLE 1 . The percentage of male's subjects was $58 \%$ and the mean age was $48.1 \pm 9.4$ years. The mean BMI was $26.39 \pm 4.7 \mathrm{~kg} / \mathrm{m}^{2}$ and mean HOMA-IR was $3.02 \pm 2$.

TABLE 1. Baseline characteristic of patients undergoing therapy for HCV genotype 3.

\begin{tabular}{|c|c|}
\hline Variables & Genotype 3 \\
\hline $\mathrm{N}(\%)$ & $200(100)$ \\
\hline Age * & $48.1(9.4)$ \\
\hline Male, n (\%) & $107(53.5)$ \\
\hline AST $(\mathrm{ULN}) *$ & $1.9(1.4)$ \\
\hline $\operatorname{ALT}(\mathrm{ULN}) *$ & $2.3(1.8)$ \\
\hline GGT $(\mathrm{ULN}) *$ & $2.3(2.0)$ \\
\hline Platelets $(10 \mathrm{e} 9 / \mathrm{L})^{*}$ & $183.5(76.7)$ \\
\hline Viral load, n (\%) & $157(100)$ \\
\hline$<400.000 \mathrm{UI} / \mathrm{mL}$ & $79(50.3)$ \\
\hline$\geq 400.000 \mathrm{UI} / \mathrm{mL}$ & $78(49.7)$ \\
\hline BMI $\left(\mathrm{kg} / \mathrm{m}^{2}\right)^{*}$ & $26.3(4.7)$ \\
\hline HOMA-IR* & $3.0(2.0)$ \\
\hline HOMA-IR $\geq 2.5$ n (\%) & $113(56.5)$ \\
\hline Cholesterol $(\mathrm{mg} / \mathrm{dL})^{*}$ & $151.7(40.7)$ \\
\hline HDL- Cholesterol $(\mathrm{mg} / \mathrm{dL})^{*}$ & $47.9(18.4)$ \\
\hline Triglycerides $(\mathrm{mg} / \mathrm{dL})^{*}$ & $94.8(48.3)$ \\
\hline Fibrosis score, n (\%) & $200(100)$ \\
\hline $0-1-2$ & $113(56.5)$ \\
\hline 3 e 4 & $87(43.5)$ \\
\hline Activity score, n (\%) & $170(100)$ \\
\hline A0 & $33(19.41)$ \\
\hline A1 & $52(30.59)$ \\
\hline A2 & $71(41.76)$ \\
\hline A3 & $14(8.24)$ \\
\hline Steatosis, $\mathrm{n}(\%)$ & $162(100)$ \\
\hline Grade 0 & $66(40.7)$ \\
\hline Grade 1 & $60(37)$ \\
\hline Grade 2 & $26(16)$ \\
\hline Grade 3 & $10(6.3)$ \\
\hline SVR, n (\%) & $145 / 200(72.5 \%)$ \\
\hline Advanced fibrosis, $\mathrm{n}(\%)$ & $52 / 87(59 \%)$ \\
\hline
\end{tabular}

* Variables reported as mean (SD). HCV: chronic hepatitis C; AST: aspartate aminotransferase; ULN: upper limit of normalization; ALT: Alanine aminotransferase; GGT: gamma-glutamyl transpeptidase; BMI: body mass index; IR: insulin resistance; HDL: high density lipoprotein; SVR: sustained virological response. 
Advanced fibrosis (F3-F4) was found in $43.5 \%$ of the patients and $59.1 \%$ of then had steatosis. The inflammatory activity classified as A3-A4 was seen in $50 \%$ of cases $(85 / 170)$.

SVR was achieved in $145(72.5 \%)$ patients. TABLE 2 describes the demographic, clinical, biochemical, histological and viral characteristic of patients by virological response.

TABLE 2. Clinical, biochemical, histological and viral characteristic of the patients regarding virological response - univariate analysis.

\begin{tabular}{lccc}
\hline Genotype 3 & SVR & No-SVR & P value \\
\hline N (\%) & $145(72.5 \%)$ & $55(27.5)$ & \\
Age* & $46.4(9.4)$ & $52.5(7.8)$ & 0.001 \\
Male, n (\%) & $80(74.7)$ & $27(25.3)$ & 0.44 \\
AST (ULN)* & $1.8(1.3)$ & $2.3(1.4)$ & 0.03 \\
ALT (ULN)* & $2.2(1.9)$ & $2.5(1.7)$ & 0.35 \\
GGT (ULN)* & $2.3(2.1)$ & $2.3(1.8)$ & 0.84 \\
Platelets (10e9/L)* & $191.9(73.9)$ & $161.5(80.2)$ & 0.01 \\
Viral load, n (\%) & $107(68.2)$ & $50(31.8)$ & \\
s400.000 UI & $56(70.9)$ & $23(29.1)$ & 0.42 \\
>400.000 UI/mL & $51(65)$ & $27(35)$ & \\
BMI (kg/m $)^{*}$ & $26.28(4.95)$ & $26.66(4.2)$ & 0.62 \\
HOMA-IR* & $2.82(2.0)$ & $3.54(2.17)$ & 0.004 \\
Cholesterol (mg/dL)* & $154.5(41.9)$ & $146.5(38.4)$ & 0.33 \\
HDL- Cholesterol & $49.6(18)$ & $44.8(19.2)$ & 0.26 \\
(mg/dL)* & $94.8(48.9)$ & $95.05(47.7)$ & 0.98 \\
Triglycerides (mg/dL)* & & & \\
Fibrosis score, n (\%) & $93(82)$ & $20(17)$ & 0.001 \\
0-1-2 & $52(59)$ & $35(41)$ & \\
3 e 4 & & & \\
Activity score, n (\%) & $17(51)$ & $16(49)$ & 0.306 \\
A0 & $27(51)$ & $25(49)$ & \\
A1 & $40(56)$ & $31(44)$ & \\
A2 & $4(28)$ & $10(72)$ & \\
A3 & & & \\
Steatosis, n (\%) & $44(66)$ & $22(44)$ & 0.761 \\
Grade 0 & $37(61)$ & $23(39)$ & \\
Grade 1 & $7(27)$ & \\
Grade 2 & $3(30)$ & \\
Grade 3 & & & \\
\hline
\end{tabular}

* Variables reported as mean $(\mathrm{SD}), P$ value $=0.05 . \mathrm{SVR}$ : sustained virological response; AST: aspartate aminotransferase; ULN: upper limit of normalization; ALT: Alanine aminotransferase; GGT: gamma-glutamyl transpeptidase; IR: insulin resistance; HDL: high density lipoprotein.

Patients who achieved SVR were younger $(46.6 \pm 9.4$ vs $52.5 \pm 7.8 ; P<0.001)$, had lower AST $(1.8 \pm 1.3$ vs $2.3 \pm 1.4 P=0.03)$, lower stages of fibrosis (F0-F2 64\% X F3-F4 36\%, $P<0.0001)$ and higher platelets counts. (191.9 \pm 73.9 vs $161.5 \pm 80.2 ; P=0.01)$. Lower indices of IR prior to treatment compared to those who did not $(2.82 \pm 2$ vs $3.54 \pm 2.1 ; P=0.02)$ were also associated with the achievement of SVR. HOMA-IR was also used as categorical variable and categorized in three different cut-offs (HOMA-IR $=2$; HOMA-IR $\geq 2.5$ and HOMA-IR $=3$ ). The cut-off of HOMA-IR $\geq 2.5$ was used due to the best coefficient of correlation with SVR compared to either HOMA-IR $=2$ or HOMA-IR $=3$. [HOMA-IR $\geq 2.5$ : $\mathrm{rS}=0.202 ; P=0.004 ; \mathrm{HOMA}-\mathrm{IR}=2: \mathrm{rS}=0.164 ; P=0.02$; HOMA-IR $=3 ; \mathrm{rS}=0.167 ; P=0.018]$.

In univariate analysis, patients with HOMA-IR $\geq 2.5$ had 2.6 times lower likelihood of achieving SVR [OR=2.63 (95\% CI: 1.336-
5.175) $P=0.005]$. However, in the multivariate analysis, only age [OR=1.064 (95\%CI: 1.021-1.109) $P=0.003$ ] was associated with SVR, and advanced fibrosis [OR $=1.939$ (95\%CI: $0.900-4.179)$ $P=0.09$ ] trended towards a positive association with SVR. After adjusting for platelets as a confounding factor, age [OR $=1.065$, (95\% CI: $1.022-1.110), P=0.002]$ and advanced fibrosis $[\mathrm{OR}=2.01$ (95\%CI: 0.986-4.119), $P=0.05]$ were significantly associated with SVR (TABLE 3). HOMA-IR did not reach significance as a predictor of SVR in multivariate analysis.

TABLE 3. Predictive factors associated with SVR - logistic regression analysis adjusted by platelets.

\begin{tabular}{lccc}
\hline Variables & OR & 95\%CI & $\boldsymbol{P}$ value \\
\hline Age & 1.065 & $1.022-1.110$ & $\mathbf{0 . 0 0 2}$ \\
AST & 1.091 & $0.861-1.382$ & 0.47 \\
Advanced fibrosis & 2.015 & $0.986-4.119$ & 0.05 \\
HOMA-IR $\geq 2.5$ & 1.629 & $0.781-3.401$ & 0.193 \\
\hline
\end{tabular}

AST: aspartate aminotransferase; OR: odds ratio; IR: insulin resistance.

Gender, ALT, GGT, lipid panel, viral load, BMI, presence of steatosis and inflammatory activity were not found to be significantly associated with SVR.

\section{DISCUSSION}

In HCV genotype 3 positive patients who are treated with PEG/RBV, several demographics, biochemical, virological and histological factors have been associated with SVR. In three large studies, it was found that viral load, age, weight, BMI and advanced fibrosis were the most important pretreatment predictors of SVR in genotype 3 positive patients who received Peg/RBV treatment ${ }^{(33-35)}$. However, these studies did not assess the effect of IR on SVR.

This study confirms previous reports that age and advanced fibrosis are predictors of SVR in genotype 3 positive patients ${ }^{(36,37)}$. For every 6-year increment of age, we found that the likelihood of SVR decreased by $6 \%$. It has been postulated that older HCVinfected patients have decreased rates of SVR to interferon-based therapies because they have higher rates of comorbidities, decreased treatment tolerance, and increased adverse events from antiviral treatment. Older infected patients also have had HCV longer allowing for more extensive liver damage compared to younger patients ${ }^{(38,39)}$. In this study, patients with advanced fibrosis were older than those with mild or absent fibrosis (51 years for those with advanced fibrosis versus 45.7 years old for those with mild or absent fibrosis, $P<0.0001)$.

In $\mathrm{HCV}$ genotype 3 positive patients who had bridging fibrosis and cirrhosis, the likelihood of achieving SVR was reduced by two fold compared to patients with mild or no fibrosis (F0-F2). This finding supports previous studies which also showed that the presence of advanced fibrosis is a negative predictive factor of SVR in genotype 3 patients ${ }^{(31-33,40-43)}$.

This is the first study to assess the impact of IR on SVR in 200 $\mathrm{HCV}$ genotype 3 patients treated with $\mathrm{PEG} / \mathrm{RBV}$. Prior studies have tried to understand this effect but they grouped genotype 2 and genotype 3 together in analysis preventing the ability to determine effects of IR on HCV genotype 3 alone ${ }^{(19,20)}$. In addition, a majority of previous studies had small samples sizes with contradictory results precluding any conclusion ${ }^{(15,17,18)}$. 
Fatovichi et al. showed that IR was a predictor of rapid virological response (RVR), but BMI was the only factor associated with SVR ${ }^{(14)}$. On the other hand, Eslam et al. studied 48 genotype 3 patients and found that IR was a significant predictor of early and late viral kinetics, and that IR was a negative predictor of SVR mentioned only in univariate analysis ${ }^{(15)}$. In this study, we did not explore the relationship between RVR and IR as RVR determination is not mandatory in Brazilian guidelines ${ }^{(30)}$.

IR was assessed in our study using HOMA-IR, which has been shown to be correlated closely with the hyperinsulinemic euglycemic clamp technique ${ }^{(44)}$. Since there is no absolute cut-off value for HOMA-IR to diagnose IR in HCV patients, we established our cut-off value to be 2.5 due to the coefficient of correlation with SVR of $\mathrm{rS}=0.202(P=0.004)$. In this study, $56.5 \%$ of patients had HOMA-RI $\geq 2.5$ and they were older compared to those without IR (50.5 years for patients with IR versus 44.9 years for those without IR, $P<0.0001$ ).

Some studies have shown that the presence of parameters associated with IR such as DM and metabolic syndrome can also affect SVR rates. Shoeb D et al. estimated that the likelihood of SVR from PEG/RBV was reduced by $62 \%$ among HCV genotype 3 patients with $\mathrm{DM}^{(36)}$. Aziz et al. showed that $\mathrm{HCV}$ genotype 3 positive patients without metabolic syndrome who were treated with interferon based therapy had higher SVR rates compared to patients with metabolic syndrome $(72.2 \% \text { vs } 43.7 \% P<0.05)^{(45)}$. However, they included diabetic patients in their analysis. Our study aimed to examine the effects of IR on SVR rates in patients with IR but not DM.

In this study, the univariate analysis showed that in patients with HOMA-IR $\geq 2.5$, the likelihood of achieving SVR was reduced by 2.6 fold compared to patients with HOMA-IR $<2.5[\mathrm{OR}=2.630$ (95\%CI: 1.336-5.175) $P=0.005$ ]. Age and advanced fibrosis were the only negative predictors of SVR in multivariate analysis. A sub-analysis per center was also done and no significant differences in the effect of IR on SVR were seen (data not showed). IR as predictive value for SVR founded in the univariate analysis merely reflects its relationship with age and degree of fibrosis which were seen as independent predictors of SVR in our patients.

Thompson et al. showed that HCV genotype 3 positive patients who achieved SVR did not have a significant reduction in mean of HOMA-IR after treatment, which suggests that different factors could be involved with IR in patients with genotype $3^{(46)}$. In this study, the factors associated with HOMA-IR $\geq 2.5$ were age [OR=1.06 (95\%CI: 1.022-1.107) $P=0.002]$, advanced fibrosis [OR= 2.66 (95\%CI: $1.258-5.635) P=0.01]$, BMI [OR $=1.19$ (95\% CI: $1.092-$ 1.308) $P<0.001]$ and ALT [OR $=1.51(95 \%$ CI: $1.085-2.117) P=0.01]$.

As this was a retrospective study, data for steatosis and $\mathrm{HCV}$ RNA levels was limited, only $81 \%$ and $78 \%$ of the patients had information on the degree of steatosis and HCV-RNA levels, respectively. Lack of data could explain why either steatosis or HCV RNA levels did not reach significance. However, in prior studies, there is no clear consensus regarding the relationship between steatosis and SVR in genotype 3 positive patients ${ }^{(33-35,47)}$. On the other hand, HCV viral load has been previously shown to be associated with $\mathrm{SVR}^{(33-35)}$. Even after changing the HCV-RNA cut-off value to $8000.000 \mathrm{U}$ I/L in our analysis, HCV-RNA levels still did not reach significance as a predictor of SVR in our study.

Our findings show that IR when measured by HOMA-IR, does not play a role in achieving SVR in non-diabetic patients with $\mathrm{HCV}$ genotype 3 who are treated with PEG/RBV. Despite the increased use of new interferon-free HCV therapies, interferon-based therapies still play a role in treating cirrhotic and previously-treated genotype 3 positive patients ${ }^{(33,48)}$, and remain as a viable option for treating genotype 3 patients in Latin American, Africa and Middle West countries ${ }^{(34)}$.

\section{Authors' contribution}

Dr. Laurito and Dr. Parise were responsible for study design, data collection, analysis and interpretation as well as writing the manuscript. Dr. Cheinquer and Dr. Faria were responsible for data collection at their institution. Dr. Verna was responsible for data analysis and Dr. Sharma helped on the revision of the manuscript.

Laurito MP, Silva GF, Cheinquer H, Sharma R, Verna E, Parise ER. Resistência insulínica interfere na resposta virológica sustentada em pacientes portadores de hepatite C crônica genótipo 3 tratados com peginterferon/ribavirina? Arq Gastroenterol. 2018;55(2):179-83.

RESUMO - Contexto - A resistência insulínica e o diabetes mellitus são frequentes manifestações extra-hepáticas da hepatite C crônica. A resistência insulínica medida pelo HOMA-IR está associada a uma baixa taxa de resposta virológica sustentada, principalmente em pacientes portadores de hepatite C crônica genótipo 1 tratados com peginterferon/ribavirina. Em relação aos pacientes portadores de hepatite $\mathrm{C}$ crônica genótipo 3 tratados com peginterferon/ ribavirina, a influência da resistência insulínica na resposta virológica sustentada ainda não está esclarecida. Objetivo - Avaliar a influência da resistência insulínica na resposta virológica sustentada em pacientes portadores de hepatite C crônica genótipo 3. Métodos - Estudo multicêntrico retrospectivo foi realizado para avaliar a influência da resistência insulínica na resposta virológica sustentada em pacientes não-diabéticos portadores de hepatite $\mathrm{C}$ crônica genótipo 3 tratados com peginterferon/ribavirina. Um total de 200 pacientes portadores de hepatite C crônica genótipo 3 foi incluído no estudo. Todos os pacientes eram não diabéticos e apresentavam medida de HOMA-IR antes do início do tratamento da hepatite C crônica com peginterferon/ ribavirina. A duração do tratamento foi de pelo menos 24 semanas. O cut-off de HOMA-IR foi definido para este estudo como $\geq 2,5$ devido ao coeficiente de correlação com a resposta virológica sustentada de 0,202 ( $P=0,004)$. Resultados - Na análise univariada, idade, aspartato aminotransferase, plaquetas, grau de fibrose e HOMA-IR foram preditores de resposta virológica sustentada. No entanto, na análise multivariada, apenas fibrose avançada [OR=2,01 (95\%IC: 0,986-4,119) $P=0,05]$ e idade [OR=1,06 (95\%IC: 1,022-1,110) $P=0,002$ ] estavam relacionados como preditores negativo de resposta virológica sustentada. Conclusão - Neste estudo multicêntrico, retrospectivo, em pacientes não diabéticos portadores de hepatite C genótipo 3, a resistência insulínica não estava associada à resposta virológica sustentada em pacientes tratados com peginterferon/ribavirina.

DESCRITORES - Hepatite C crônica. Genótipo. Resistência à insulina. Ribavirina. Antivirais. 


\section{REFERENCES}

1. Delgado-Borrego A, Casson D, Schoenfeld D, Somsouk M, Terella A, Jordan $\mathrm{SH}$, et al. Hepatitis $\mathrm{C}$ virus is independently associated with increased insulin resistance after liver transplantation. Transplantation. 2004;77:703-10.

2. Delgado-Borrego A, Liu-Sheen L, Jordan SH, Agrawal S, Zhang H, Christofi $\mathrm{M}$, et al. Prospective study of liver transplant recipients with HCV infection: evidence for causal relationship between HCV and Insulin resistance. Liver Transp. 2008;14:193-201.

3. Fraser GM, Harman I, Meller N, Niv Y, Porath A. Diabetes mellitus is associated with chronic hepatitis $\mathrm{C}$ but not chronic hepatitis B infection. Isr J Med Sci. 1996;32:526-30.

4. Mehta SH, Starthdee SA, Thomas DL. Association between hepatitis Cvirus infection and diabetes mellitus. Epidemiol Rev. 2001;23:302-12.

5. Allison ME, Wreighitt T, Palmer CR, Alexander GJ. Evidence for a link between hepatitis $\mathrm{C}$ virus infection and diabetes mellitus in a cirrhotic population. $\mathrm{J}$ Hepatol. 1994;21:1135-9.

6. Negro F. Steatosis and insulin resistance in response to treatment of chronic hepatitis C. J Viral Hepatitis. 2012;19:42-7.

7. Kawaguchi $\mathrm{Y}$, Mizuta T. Interaction between hepatitis $\mathrm{C}$ virus and metabolic factors. W J Gastroenterol. 2014;20:2888-901.

8. Persico M, Capasso M, Persico E, Svelto M, Russo R, Spano D, et al. Suppressor of cytokine signaling 3 (SOCS3) expression and hepatitis $\mathrm{C}$ virus-related chronic hepatitis: insulin resistance and response to antiviral therapy. Hepatology. 2007;46:1009-15.

9. Romero-Gomez M, Del Mar Viloria M, Andrade RJ, Salmerón J, Diago M, Fernández-Rodríguez CM, et al. Insulin resistance impairs sustained response rate to peginterferon plus ribavirin in chronic hepatitis $\mathrm{C}$ patients. Gastroenterology. 2005;128:636-41.

10. Kamaguchi T, Ide T, Taniguchi E, Hirano E, Itou M, Sumie S, et al. Clearance of $\mathrm{HCV}$ improves insulin resistance, beta-cell function and hepatic expression of insulin receptor substrate 1 and 2. Am J Gastoenterol. 2007;102:570-6.

11. Arase Y, Suzuki F, Suzuki Y, Akuta N, Kobayashi M, Kawamura Y, et al. Sustained virological response reduces incidence of onset of type 2 diabetes in chronic hepatitis C. Hepatology. 2009;49:739-44.

12. Romero-Gomez M. Insulin resistance and hepatitis C. World J Gastroenterol. 2006; $12: 7075-80$.

13. Dai CY, Huang JF, Hsieh MY, Hou NJ, Lin ZY, Chen SC, et al. Insulin resistance predicts response to peginterferon-alpha/ribavirin combination therapy in chronic hepatitis C patients. J Hepatol. 2009;50:712-8.

14. Fattovich G, Covolo L, Pasino M, Perini E, Rossi L, Brocco G, et al. The homeostasis model assessment of the insulin resistance score is not predictive of a sustained virological response in chronic hepatitis $\mathrm{C}$ patients. Liver Int. 2011;31:66-74

15. Eslam M, Aparcero R, Mousa YI, Grande L, Shaker Y, Ali A, et al. Insulin resistance impairs viral dynamics independently of ethnicity or genotypes. J Clin Gastroenterol. 2012;46:228-34.

16. Miyaaki H, Ichikawa T, Nakao K, Matsuzaki T, Muraoka T, Honda T, et al. Predictive value of suppressor of cytokine signal 3 (SOCS3) in the outcome of interferon therapy in chronic hepatitis C. Hepatol Res. 2009;39:850-5.

17. Poustchi H, Negro F, Hui J, Cua IH, Brandt LR, Kench JG, George J. Insulin resistance and response to therapy in patients infected with chronic hepatitis $\mathrm{C}$ virus genotypes 2 and 3. J Hepatol. 2008;48:28-34.

18. Bortoletto G, Scribano L, Realdon S, Marcolongo M, Mirandola S, Franceschini $\mathrm{L}$, et al. Hyperinsulinaemia reduces the 24-h virological response to PEG-interferon therapy in patients with chronic hepatitis $\mathrm{C}$ and insulin resistance. J Viral Hepat. 2010;17:475-80.

19. Laurito MP, Parise ER. Association between insulin resistance and sustained virologic response in hepatitis $\mathrm{C}$ treatment, genotype 1 versus 2 and 3: systematic literature review and meta-analysis. Braz J Infect Dis. 2013;17:555-63.

20. Eslam M, Aparcero R, Kawaguchi T, Del Campo JA, Sata M, Khattab MA, et al. Meta- analysis: insulin resistance and sustained virological response in Hepatitis C. Aliment Pharmacol Ther. 2011;34:297-305.

21. Gower E, Estes C, Blach S, RazaviShearer K, Razavi H. Global epidemiology and genotype distribution of the hepatitis C virus infection. J Hepatol. 2014;61 (Suppl): S45-S57.

22. Bochud PY, Chai T, Overbeck K, Bochud M, Dufour JF, Müllhaupt B, et al. Genotype 3 is associated with accelerated fibrosis progression in chronic hepatitis C. J Hepatol. 2009;51:655-66.

23. Kanwal F, Kramer JR, Ilyas J, Duan Z, El-Serag HB. HCV genotype 3 is associated with an increased risk of cirrhosis and hepatocellular cancer in a national sample of U.S. Veterans with HCV. Hepatology. 2014;60:98-105.

24. EASL recommendation on Treatment of Hepatitis C 2015. J Hepatol. 2015;63:199-236

25. Hepatitis C guidance: AASLD-ISDA recommendations for testing, managing, and treating adults infected with hepatitis C virus. Hepatology. 2015;62:932-54.
26. Goossens N, Negro F. Is genotype 3 of thr Hepatitis C virus the new villain? Hepatology. 2014;59:2403-12.

27. Buti M, Llaneras J, Riveiro-Barciela M, Esteban R. Therapy for hepatits C genotpe 3: moving forward. J Viral Hepat. 2015;22:683-90.

28. Foster GR, Pianko S, Brown A, Forton D, Nahass RG, George J, et al. Efficacy of sofosbuvir plus ribavirin with or without peginterferon-alfa in patients with hepatitis $C$ virus genotype 3 infection and treatment-experienced patients with cirrhosis and hepatitis $C$ virus genotype 2 infection. Gastroenterology. 2015;149:1462-70.

29. McGowan CE, Monis A, Bacon BR, Mallolas J, Goncales FL, Goulis I, et al. A global view of hepatitis $\mathrm{C}$ : physician knowledge, opinions, and perceived barriers to care. Hepatology. 2013;57:1325-32.

30. Protocolo Clinico e Diretrizes Terapeutica para Hepatitie Ce Coinfeccoes. Brasilia 2011. [Internet]. [Assessed 2016 Sept 3]. Available from: http://bvsms.saude.gov. br/bvs/publicacoes/protocolos_diretrizes_hepatite_viral_c_coinfeccoes.pdf

31. Taura N, Ichikawa T, Hamasaki K, Nakao K, Nishimura D, Goto T, et al. Association between liver fibrosis and insulinsensitivity in chronic hepatitis $\mathrm{C}$ patients. Am J Gastroenterol. 2006;101:2752-9.

32. Bedossa P, Poynard T. An algorithm for the grading of activity in chronic hepatitis C. The METAVIR Cooperative Study group. Hepatology. 1996;24:289-93.

33. Shiffman ML, Suter F, Bacon BR, Suter F, Bacon BR, Nelson D, Harley H, Solá $\mathrm{R}$, et al. Peginterferon alfa-2a and ribavirin for 16 or 24 weeks in HCV genotype 2 or 3. N Engl J Med. 2007;357:124-34.

34. Nelson DR, Benhamou Y, Chuang WL, Lawitz EJ, Rodriguez-Torres M, Flisiak $\mathrm{R}$, et al. Albinterferon Alfa-2b was not inferior to pegylated interferon- $\triangle$ in a randomized trial of patients with chronic hepatitis $C$ virus genotype 2 or 3 . Gastroenterology. 2010;139:1267-76.

35. Marcellin P, Cheinquer H, Curescu M, Dusheiko GM, Ferenci P, Horban A, et al. High Sustained virologic response rates in rapid virlogic response patients in the large real-world PROPHESYS cohort confirm results from randomized clinical trials. Hepatology. 2012;56:2039-50.

36. Shoeb D, Rowe IA, Freshwater D, Mutimer D, Brown A, Moreea S, et al. Response to antiviral therapy in patients with genotype 3 chronic hepatitis $\mathrm{C}$ : fibrosis but not race encourages relapse. Eur J Gatroenterol Hepatol. 2011;23:747-53.

37. Shiffman ML, Cheinquer H, Berg CP, Berg T, de Figueiredo-Mendes C, Dore GJ, et al. Extended treatment with pegylated interferon alfa/ribavirin in patients with genotype $2 / 3$ chronic hepatitis $\mathrm{C}$ who do not achieve a rapid virological response: final analysis of the randomised N-CORE trial. Hepatol Int. 2014;8:517-26.

38. Zeuzem S. Heterogeneous Virologic Response Rates to Interferon-Based Therapy in Patients with Chronic Hepatitis C: Who Responds Less Well? Ann Intern Med. 2004; 140:370-81.

39. Huang CF, Yang JF, Dai CY, Huang JF, Hou NJ, Hsieh MY, et al. Efficacy and safety of pegylated interferon combined with ribavirin for the treatment of older patients with chronic hepatitis C.J Infect Dis. 2010;201:751-9.

40. Butt AS, Mumtaz K, Aqeel I, Shah HA, Hamid S, Jafri W. Sustained virological response to pegylated interferon and ribavirin in patients with genotype $3 \mathrm{HCV}$ cirrhosis. Trop Gastroenterol. 2009;30:207-12.

41. Marciano S, Borzi SM, Dirchwolf M, Ridruejo E, Mendizabal M, Bessone F, et al. Pre- treatment prediction of response to peginterferon plus ribavirin in chronic hepatitis C genotype 3. World J Hepatol. 2015;7:703-9.

42. Mangia A, Bandiera F, Montalto G, Mottola L, Piazzolla V, Minerva N, et al. Individualized treatment with combination of Peg-interferon alpha $2 \mathrm{~b}$ and ribavirin in patients infected with HCV genotype 3. J Hepatol. 2010;53:1000-5.

43. Shoeb D, Dearden J, Weatherall A, Bargery C, Moreea S, Alam S, et al. Extended duration therapy with peguilated interferon and ribavirin for patients with genotype 3 hepatitis $\mathrm{C}$ and advanced fibrosis: final results from the STEPS trial. J Hepatol. 2014;60:699-705.

44. Eslam M, Kawaguchi T, Del Campo JA, Sata M, Khattab MA, Romero-Gomez M. Use of HOMA-IR in hepatitis C. J Viral Hepatol. 2011;18:675-84.

45. Aziz H, Gill U, Raza A, Gill ML. Metabolic syndrome is associated with poor treatment response to antiviral therapy in chronic hepatitis $\mathrm{C}$ genotype 3 patients. Eur J Gastroenterol Hepatol. 2014;26:538-43.

46. Thompson AJ, Patel K, Chuang WL, Lawitz EJ, Rodriguez-Torres M, Rustgi VK, et al. Viral clearance is associated with improved insulin resistance in genotype 1 chronic hepatitis C but not genotype 2/3. Gut. 2012;61:128-34.

47. Shah SR, Patel K, Marcellin P, Foster GR, Manns M, Kottilil S, et al. Steatosis is an independent predictor of relapse following rapid virologic response in patients with HCV genotype 3. Clin Gastroenterol Hepatol. 2011;9:688-93.

48. Lawitz E, Poordad F, Brainard DM, Hyland RH, An D, Dvory-Sobol H, et al. Sofosbuvir with peginterferon-ribavirin for 12 weeks in previously treated patients with hepatitis C genotype 2 or 3 and cirrhosis. Hepatology. 2015:61:769-75.

$(c)$ Br-NC 